Zimbalist, Zack: Explaining variation in levels of public (dis)trust in traditional leaders: colonial ruling strategies and contemporary roles in governance / Zack Zimbalist. - In: Government \& opposition (Cambridge), 56 (2021) 4, S. 661-682, graph. Darst., Lit. S. 680-682, Lit.Hinw.

\title{
ASIEN / ASIA
}

Advancement of human rights in India: contemporary and emerging challenges / Debarati Halder, Shrut S. Brahmbhatt (eds.). - Los Angeles: SAGE, 2021 - xix, 350S. ISBN 978-93-5388-785-8

Amirapu, Amrit: Justice delayed is growth denied: the effect of slow courts on relationship-specific industries in India / Amrit Amirapu. - In: Economic development and cultural change (Chicago), 70 (2021) 1, S. 415-451

Ashraf, Ali: Humanitarianism, national security, and the Rohingya refugee policy of Bangladesh / Ali Ashraf. - In: Strategic analysis (Abingdon), 45 (2021) 3, S. 184-206, graph. Darst.

Baloch, Bilal A.: When ideas matter: democracy and corruption in India / Bilal A. Baloch. - Cambridge: Cambridge University Press, 2021 - xxiii, 325S., Lit. (South Asia in the social sciences) ISBN 978-1-316-51983-7

Barber, Rebecca; Teitt, Sarah: Legitimacy and centrality under threat: the case for an ASEAN response to human rights violations against the Rohingya / Rebecca Barber, Sarah Teitt. - In: Asian politics \& policy (Hoboken, NJ), 13 (2021) 4, S. 471-492

Brysk, Alison: Constructing rights in Taiwan: the feminist factor, democratization, and the quest for global citizenship / Alison Brysk. - In: The Pacific review (London), 34 (2021) 5, S. 838-870

Cannon, Mariah; Oosterhoff, Pauline: Bonded: life stories from agricultural communities in SouthEastern Nepal / Mariah Cannon, Pauline Oosterhoff. - Brighton: Institute of Development Studies, 2021 - [Elektronische Ressource (51S.)] (CLARISSA working paper; 6)

Cho, Sungmin: Why non-democracy engages with western democracy-promotion programs: the China model / Sungmin Cho. - In: World politics (Cambridge), 73 (2021) 4, S. 774-817, Ill., Lit. S. 807-817, Lit.Hinw.

Cimmino, Jeffrey: A strategic framework for countering China's human-rights violations in Xinjiang / Jeffrey Cimmino. - Washington, DC: Atlantic Council, 2021 - [Elektronische Ressource (19S., Ill.)] (Issue brief)

Croydon, Silvia: Prisoners' rights implementation in Japan: breaking the shackles with suspects / Silvia Croydon. - In: Japanese journal of political science (Cambridge), 22 (2021) 3, S. 163-174

Davis, Sasha: Islands and oceans: reimagining sovereignty and social change / Sasha Davis. - Athens: The University of Georgia Press, 2020 - viii, 171S., Ill., Lit. S. 151-166, Lit.Hinw. S. 147-149 (Geographies of justice and social transformation; 48) ISBN 978-0-8203-5735-5; 978-0-8203-5733-1

Dhume, Sadanand: How democratic is the world's largest democracy? / Sadanand Dhume. - In: Foreign affairs (New York), 100 (2021) 5, S. 209-215

Doyle, Kevin J.: Co-opted social media and the practice of active silence in Cambodia / Kevin J. Doyle. - In: Contemporary Southeast Asia (Singapore), 43 (2021) 2, S. 293-320

Fewsmith, Joseph: Rethinking Chinese politics / Joseph Fewsmith. - Cambridge: Cambridge University Press, 2021 - xi, 217S., Ill., Lit. ISBN 978-1-108-83125-3; 978-1-108-92660-7 
Gamso, Jonas: Is China exporting media censorship? China's rise, media freedoms, and democracy / Jonas Gamso. - In: European journal of international relations (London), 27 (2021) 3, S. 858-883, graph. Darst., Lit. S. 877-882

"Going out" responsibly: the human rights impact of China's global investments / Business \& Human Rights Resource Centre. - London: Business \& Human Rights Resource Centre, 2021 - [Elektronische Ressource (34S., Ill.)]

Hall, Ian; Jeffery, Renée: India, the Rome Statute, and the International Criminal Court / Ian Hall, Renée Jeffery. - In: Global governance (Leiden), 27 (2021) 3, S. 460-482

Huang, Yanzhong: The myth of authoritarian superiority: China's response to Covid-19 revisited / Yanzhong Huang. - In: China leadership monitor (Stanford), 68 (2021), S. 1-15

Inoguchi, Takashi: Japanese politics in comparative perspective: from the East to the West, and then whither? / Takashi Inoguchi. - New York: Peter Lang Publishing Inc., 2021 - xv, 285S. (Peter Lang regional studies list) ISBN 978-1-4331-8549-6

Jain, Ash; Kesselbrenner, Joel; Mattis, Peter: Hong Kong's future on edge: countering China's National Security Law / Ash Jain, Joel Kesselbrenner, Peter Mattis. - Washington, DC: Atlantic Council, 2021 - [Elektronische Ressource (14S., Ill.)]

Jha, Himanshu: Capturing institutional change: the case of the Right to Information Act in India / Himanshu Jha. - New Delhi: Oxford University Press, 2020 - xxii, 318S., Ill., Lit. S. 277-306 (Institutions and development in South Asia) ISBN 978-0-19-012478-6

Kapur, Roshni; Attanayake, Chulanee: Human rights, geopolitics and national priorities: managing fluctuations in US-Sri Lanka relations / Roshni Kapur, Chulanee Attanayake. - Singapore: Institute of South Asian Studies, National University of Singapore, 2021 - [Elektronische Ressource (9S.)] (ISAS working paper; 344)

Khosla, Madhav; Vaishnav, Milan: The three faces of the Indian state / Madhav Khosla, Milan Vaishnav. - In: Journal of democracy (Baltimore, Md), 32 (2021) 1, S. 111-125

Kim, Taekbin: Who is purged? Determinants of elite purges in North Korea / Taekbin Kim. - In: Communist and post-communist studies (Oakland), 54 (2021) 3, S. 73-96, graph. Darst.

King, Robert R.: Patterns of impunity: human rights in North Korea and the role of the U.S. special envoy / Robert R. King. - Washington, D.C: Brookings Institute Press, 2021 - xii, 346S., Lit. ISBN 978-1-931368-62-9

Kochanski, Adam: Framing, truth-telling, and the limits of local transitional justice / Adam Kochanski. - In: Review of international studies (Cambridge), 47 (2021) 4, S. 468-488, graph. Darst., Lit.Hinw.

Konečná, Lucie; Mrva, David: Refugee-related political violence in Asia and Africa / Lucie Konečná, David Mrva. - In: Central European journal of international and security studies (Prague), 15 (2021) 3, S. 55-76, Ill., graph. Darst., Lit. S. 75-76

Kwok, Dennis; Donkervoort, Elizabeth: The risks for international business under the Hong Kong National Security Law / Dennis Kwok, Elizabeth Donkervoort. - Cambridge: Ash Center for Democratic Governance and Innovation, Harvard Kennedy School, 2021 - [Elektronische Ressource (10S.)] (Occasional paper series) 